\title{
Aboriginal expectations and perceived effectiveness of forest management practices and forest certification in Ontario
}

\author{
by Shashi Kant ${ }^{1}$ and Doug Brubacher ${ }^{2}$
}

\begin{abstract}
The paper aims to develop a better understanding of Aboriginal peoples' expectations of the forest environment, and their perceptions of forest planning and management operations on Crown forestlands. The paper also examines the variation in Aboriginal expectations and perceptions across different Aboriginal communities, communities with certified and non-certified forests, three primary user groups (Traditional users, Commercial users, and Leadership), and Aboriginal people with and without knowledge of certification. The understanding is developed on the basis of data from five First Nations, two having FSC-certified forests and three having non-certified forests, all from Ontario. Data were collected using Conceptual Cognitive Content Mapping ( $3 \mathrm{CM}$ ) techniques, and were analyzed using various non-parametric statistical tests, including the Freidman test, Sign test, and Kruskal-Wallis test. We conclude that Aboriginal people place the highest importance on a group of expectations related to Aboriginal and Treaty Rights and the second highest on Environmental Values and SFM-related expectations. Expectations related to Participatory Decision-Making and Economic Opportunities and Development are ranked at the same importance level, but of lower importance than Aboriginal and Treaty Rights and Environmental Values and SFM. Aboriginal people generally perceive that forest management is meeting their expectations related to Environmental Values and SFM better than it is meeting their expectations related to Aboriginal and Treaty Rights, Participatory Decision-Making, and Economic Opportunities and Development. Forest certification is perceived to be as important as First Nation negotiations with the Ontario government, Negotiation with industry, Improved business/profitability outlook for the forest industry, Court cases and legal decisions, and Aboriginal claims filed with the federal government.
\end{abstract}

Key words: Aboriginal and treaty rights, Aboriginal expectations, Conceptual Cognitive Content Mapping (3CM), forces of change, forest certification

\section{RÉSUMÉ}

Cet article cherche à développer une meilleure compréhension des attentes des Premières Nations en matière d'environnement forestier et de leurs perceptions de la planification forestière et des opérations forestières sur le territoire forestier public. Cet article étudie également la variation dans les attentes et les perceptions des Autochtones issus de différentes communautés, communautés de forêts certifiées et de forêts non certifiées, de trois groupes d'utilisateurs primaires (les utilisateurs primaires, les utilisateurs commerciaux et les groupes de leadership) et des groupes autochtones ayant et n’ayant pas de connaissance en matière de certification. La compréhension est développée à partir de données en provenance de cinq Premières Nations, deux ayant des forêts certifiées selon FSC et trois nayant pas de forêts certifiées, toutes situées en Ontario. Les données ont été recueillies au moyen des techniques de cartographie conceptuelle du contenu cognitif et ont été analysées au moyen de tests statistiques non paramétriques, dont le test Freidman, le test Sign et le test Kruskal-Wallis. Nous avons conclu que les peuples autochtones accordent une grande importance à un groupe dattentes reliées aux Droits et traités autochtones, suivi en deuxième lieu par les attentes sur les Valeurs environnementales et l'AFD. Les attentes portant sur la Prise de décision participative et les opportunités économiques et le développement sont classées au même niveau, mais d'une importance inférieure aux Droits et traités autochtones et aux Valeurs environnementales et l'AFD. Les peuples autochtones considèrent en général que l'aménagement forestier répond à leurs attentes reliées aux Droits et traités autochtones, à la Prise de décision participative et aux opportunités économiques et au développement. La Certification forestière est considérée comme étant aussi importante que les Négociations des Premières Nations avec le gouvernement de l'Ontario, les Négociations avec l'industrie, les Prévisions favorables d'affaires et de profitabilité, les Démarches juridiques et les jugements légaux ainsi que les Procédures légales des Autochtones effectuées auprès du gouvernement fédéral.

Mots clés : droits et traits autochtones, cartographie conceptuelle du contenu cognitif, forces de changement, certification forestière

\footnotetext{
${ }^{1}$ Faculty of Forestry, University of Toronto, 33 Willcocks Street, Toronto, Ontario. E-mail: Shashi.kant@utoronto.ca (corresponding author)

${ }^{2}$ Brubacher Development Strategies Inc., 105 Caroline Avenue, Ottawa, Ontario. E-mail: dougbrubacher@sympatico.ca
} 


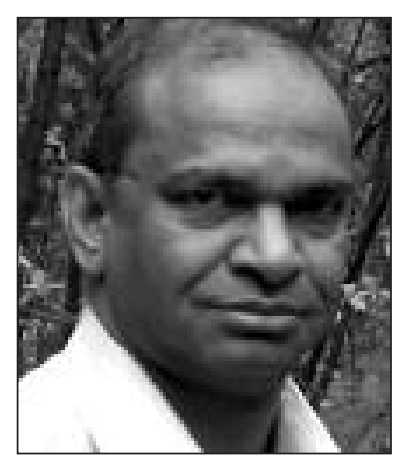

Shashi Kant

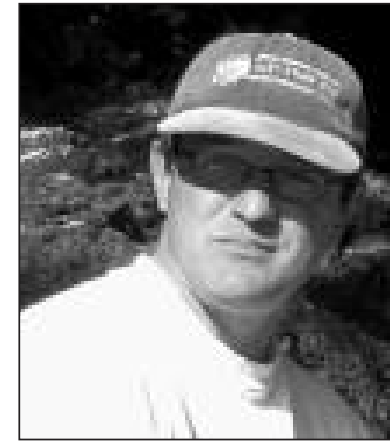

Doug Brubacher

\section{Introduction}

Forests are a critical part of the spiritual and cultural life of Aboriginal peoples, who strive to maintain healthy relationships with forest ecosystems (McGregor 2002). Over the past two centuries the relationship of Aboriginal peoples with forest ecosystems suffered a setback arising from increasing commercial utilization of these ecosystems and a decline in the influence of Aboriginal peoples in how forest resources are utilized. However, during the last two decades this situation has begun to change in response to pressures arising from Aboriginal communities. The Canadian courts, through many decisions such as Sparrow (1990), Delgamuukw (1997), Halfway River First Nation (1997), Paul (1998), Haida (2004), and Mikisew (2005), have directed the provinces to recognize and protect Aboriginal and treaty rights in their resource development and planning processes. The Government of Canada has recognized the active role of Aboriginal peoples in sustainable forest management (SFM) through the National Forest Strategy (CCFM 1998) and the Canadian Council of Forest Ministers (CCFM) Criteria and Indicators of SFM (CCFM 1995, 2003). As a result, the definition of forestry in Canada is changing and governments and forest companies are subscribing to various forest certification systems under which there are different degrees of recognition of Aboriginal values and rights (Parsons and Prest 2003).

These developments have also attracted the attention of many research scholars who have published widely on Aboriginal co-management (Notzke 1995, Rusnak 1997, Treseder and Krogman 2000, Castro and Nielson 2001, Mabee and Hoberg 2006, Stevenson 2006, Smith 2007, Wyatt 2008), incorporation of traditional ecological knowledge in forest management (Lertzman 1999; McGregor 2000, 2002; Sherry and Myers 2002), and economic joint ventures between forest industry and Aboriginal people (Brubacher 1998, Graham 1999, NAFA-IOG, 2000, Hickey and Nelson 2005, Trosper et al. 2008). Recently, some scholars (e.g., Parsons and Prest 2003, Wyatt 2008) have also attempted to define the term, "Aboriginal forestry."

In Ontario, the Environmental Assessment Board (EAB) directed the Ontario Ministry of Natural Resources (OMNR) to incorporate various conditions related to Aboriginal groups in forest management plans (EAB 1994), and these conditions have become the part of the Crown Forest Sustainability Act (CFSA) (1995) of Ontario. Section 23 of the CFSA provides a legislative basis for the province to enter into comanagement agreements with First Nations (OMNR 1995). As a result, close working relations between the province, forest industry and Aboriginal peoples are seen to be a key component of forest management in Ontario. Forest certification may play a key role in supporting these relations. The Forest Products Association of Canada (FPAC) announced in 2002 that all member companies must be third-party-certified by 2006 (Forest Certification Watch 2005).

In view of these developments, a better understanding of Aboriginal peoples' expectations from forest environment, their perceptions of forest planning and management operations on Crown forest lands, and the role of forest certification schemes in meeting Aboriginal peoples' expectations, will provide a sound basis for partnerships between Aboriginal peoples, OMNR, and forest industries. However, in refereed literature there has been no attempt to develop understanding-based on primary data-about these issues ${ }^{3}$. Most of the literature is based on conjectures about Aboriginal peoples' values and discussions with Aboriginal representatives, and even in that manner only the first element-Aboriginal peoples' expectations-has been addressed. The two other elements-Aboriginal perceptions and the role of forest certification-have not received even peripheral treatment, specifically with respect to forest management in Ontario.

In this paper, we contribute to the development of this understanding about these three elements. The paper is an outcome of a research project whose main objective was to assess whether sustainable forest management standards are meeting the expectations of Aboriginal People on the ground level, and, whether forest certification systems are contributing to improvements in how Aboriginal expectations are being met, specifically in Ontario. The whole project has two parts: (i) develop a sound understanding of Aboriginal people's expectations and perceptions of Crown forest management; (ii) conduct gap analyses of Ontario Forest Management Planning Manual, and CSA and FSC Standards of Forest Certification with respect to Aboriginal expectations of Crown forest management in Ontario. This paper is based on the first part of the project, and the second part will be published as a separate paper.

In this paper we have addressed three aspects: (i) to identify the expectations that Aboriginal peoples in Ontario have in relation to Crown forest management within their traditional lands; (ii) to examine Aboriginal peoples' perceptions of the extent to which forest management practices in Ontario meet these expectations; and, (iii) to examine the perceptions of Aboriginal peoples of the role of forest certification in meeting their expectations. In order to have a deeper understanding of Aboriginal expectations and perceptions, we examine the variations in Aboriginal expectations and perceptions across different First Nation communities, across communities with certified and non-certified forests, across three primary user groups (Traditional users, Commercial

\footnotetext{
${ }^{3}$ Lee and Kant (2006) is one exception but their study was focused on north-western Ontario and included only Aboriginal values and not perceptions of meeting their values from Crown forest management.
} 
users, and Leadership) ${ }^{4}$, and amongst Aboriginal people with and without knowledge of certification.

The study is based on data gathered in five First Nations in Ontario, two being adjacent to FSC-certified forests and three adjacent to non-certified forests. Data were collected using Conceptual Cognitive Content Mapping (3CM) techniques and analyzed using various non-parametric statistical tests. The methodology of data collection and analysis is presented in the following section. This is followed by a presentation of results and their discussion. Finally, we conclude the paper by providing some major inferences arising from the research and their implications for forest management in Ontario.

\section{Methodology}

\section{Selection of study forests and communities}

One of the main objectives of this study is to examine the influence of forest certification on the perceptions of Aboriginal people related to the management of forests within their traditional territories. Therefore, an important criterion for the selection of study communities was the association of forests and communities with forest certification. We developed a full list of certified forests in Ontario, considered the population size and adjacency characteristics of First Nation communities related to these forests, and the length of time the forests had been under the certification scheme. We narrowed the field to First Nations adjacent to four FSC-certified forests and two CSA-certified forests. In the case of the FSCcertified forests we considered the Gordon Cosens and Romeo Malette forest management units (FMUs), the Nipissing Forest, and the French-Severn Forest. The first three forests are managed entirely or significantly by Tembec, while the latter forest is managed under a community-held Sustainable Forest License (SFL) by Westwind Forest Stewardship Inc., a not-for-profit organization with community, First Nation, and industry representation on its board of directors. We selected one FSC-certified forest from the Tembec-influenced SFLs (Romeo Malette) along with the communitybased French-Severn forest. Similarly, we selected one of the CSA-certified forests (Crossroute). In a second stage, we invited specific First Nations associated with each of these certified forests in terms of their traditional lands to participate in the study. Likewise, we selected three non-certified forests to serve as controls for the certified forests along with one First Nation associated with each of these non-certified forests. Hence, in total, six FMUs and six First Nation communities were enrolled into the project. The details of enrolled FMUs and First Nations are given in Table 1. However, one of the selected First Nations, Couchiching First Nation, was ultimately unable to participate in our research project. This occurred late in the community research phase

\footnotetext{
${ }^{4}$ In our preliminary discussions at the time of formulation as well as implementation of our research project, many Aboriginal people suggested that Aboriginal expectations as well as perceptions of forest management in Ontario may vary across different forest user groups among Aboriginal people, and they suggested that we should examine these variation across at least three groups-traditional forest users, commercial forest users, and Aboriginal leadership. Accepting those suggestions, we used these groups.
}

and as a result the Aboriginal expectations and perceptions data are based on five, not six, communities.

Preliminary identification and grouping of aboriginal expectations Conceptual Cognitive Content Mapping (3CM) was used to identify Aboriginal peoples' expectations from forest management on their traditional lands and their perception of forest management and forest certification. In the first stage, an "open" 3CM exercise was carried out with a small group of Aboriginal people from the Serpent River First Nation, in January $2006^{5}$. This community is similar in location and characteristics to the target research communities, but does not lie within any of the target FMUs. The open 3CM exercise involved four steps. First, potential participants were contacted by a local liaison person and a total of nine individuals were recruited from three forest user groups-Leadership (four), Commercial forest users (three), and Traditional forest users (two). Second, an open 3CM exercise began with each individual with a general discussion about the forest, the individual's relation to the forest, their general perspectives on forest management, and the scope and process of the $3 \mathrm{CM}$ exercise. Third, the participant was given a number of blank index cards and asked to write one "expectation" on each card. To assist in getting started, participants were prompted as needed with phrases such as, "What do you expect from forest management?" and, "What needs to be done for forest management to be carried out well?" Participants were invited to use as many cards as they required. Fourth, participants were requested to group their expectations into different categories and give a name to each category.

On the basis of the response from these nine participants, the researchers developed a list of sixteen Aboriginal "expectations" of forest management and grouped these into four main classes of expectations. The sixteen expectations and four expectation groups are presented in Table 2.

\section{Community survey about aboriginal expectations and percep- tions of forest management process and forest certification}

On the basis of the sixteen expectations identified through the open 3CM, a community survey tool (available on request from the authors) was designed to collect data about Aboriginal expectations of forest management, Aboriginal perceptions of forest management practices, and the forces of change perceived by Aboriginal participants to improve forest management. At the beginning of the survey, the involvement of the National Aboriginal Forestry Association (NAFA) in the study was explained and the three objectives of the survey were introduced to the participant. The survey included three main sections: (a) Aboriginal expectations of forest management; (b) Aboriginal perceptions of meeting their expecta-

\footnotetext{
${ }^{5}$ The 3CM methodology allows participants to focus on their own expectations, rather than against a set of expectations imposed by the surveyor, and to express their own order of ranking of different expectations. The 3CM methodology has many other advantages over the standard questionnaire method (Kearney and Kaplan 1997, Kearney et al. 1998). This methodology is common in environmental literature and recently many scholars, such as Kearney et al. 1998, Kant and Lee 2004, Lee and Kant 2006, have also used it in forestry cases.
} 
First Nation

Dokis First Nation

Whitefish Lake First Nation

Mattagami First Nation

Ojibways of Pic River

Couchiching First Nation

Lac Seul First Nation
Forest Management Unit

French-Severn

Sudbury Forest

Romeo Malette

Big Pic Forest

Crossroute

Lac Seul Forest
Certification

(as of winter 2006)

and Certification Date

FSC / February 2002

Not certified (see note)

FSC / November 2004

Not certified

CSA / December 2002

Not certified

\section{SFL Holder}

Westwind

Vermilion

Tembec

Marathon Paper

Abitibi

McKenzie

Note: Sudbury Forest received FSC certification in the fall 2006, after completion of community research.

Table 2. Expectation groupings

\section{Group I: \\ Aboriginal and Treaty Rights}

E.1 Recognize and implement Aboriginal and Treaty rights...ensure that Aboriginal People can exercise their rights without interference.

E.2 Identify and map areas of importance to Aboriginal People (such as hunting and trapping, sacred areas, medicinal plant areas, and others).

E.3 Ensure that Aboriginal People have access to areas of importance to them...such as hunting and trapping, sacred areas, medicinal plant areas, areas for raw materials for crafts, firewood, and other areas.

E.4 Protect areas of importance to Aboriginal People... such as hunting and trapping, sacred areas, medicinal plant areas, and others.
E.5 Meaningful involvement of First Nations...in decisions about how Treaty forest lands are managed and used.

E.6 Regular reports by MNR and industry to First Nations... about forest operations and management aspects of importance to Aboriginal People.

E.7 Incorporate Aboriginal knowledge into forest management planning and operations. (Traditional Ecological Knowledge, Indigenous knowledge systems)

\section{Group III: \\ Environmental Values and SFM}

E.8 Tree-planting and other regeneration and management practices... on Crown forest lands to ensure that opportunities for future timber harvests for Aboriginal People are sustained.

E.9 Manage forests to ensure that forest products...(such as berries, bark, nuts, medicines, and other items)... are available for Aboriginal People to use now and in the future.

E.10 Protection of wildlife and their habitat...protect and sustain the whole forest ecosystem.

E.11 Protect water, wetlands, and watersheds.

\section{Group IV:}

Economic Opportunities and Development
E.12 Partnerships between industry, government, and First Nations...that effectively generate Aboriginal economic development based on Treaty forests.

E.13 Increased involvement by Aboriginal loggers...in harvesting timber from Treaty forest lands.

E.14 Government support for a profitable, commercial forest products industry that can provide local jobs and economic opportunities. [i.e. similar to the support that the automotive sector has occasionally been provided].

E.15 Education, training and capacity-building programs...for Aboriginal People related to forest management, employment and business opportunities.

E.16 Sharing of the revenues from Treaty forest lands...to support Aboriginal self-government. 
Table 3. Group-wise distribution of the participants from the five First Nation communities

\begin{tabular}{lccccc}
\hline Community & Certification & Leadership & Traditional & Commercial & Total \\
\hline Pic River & No & 1 & 2 & 1 & 4 \\
Whitefish lake & No & 5 & 2 & 3 & 10 \\
Dokis & FSC & 3 & 0 & 3 & 6 \\
Mattagami & FSC & 2 & 5 & 1 & 9 \\
Lac Seul & No & 3 & 12 & 9 & 35 \\
\hline Total & & 14 & & \\
\hline
\end{tabular}

tions from forest management; and (c) an assessment of the forces that may improve how expectations of forest management are met.

Once the participants' level of knowledge of forest certification had been assessed and their primary relationship to the forest (Traditional, Commercial, or Leadership) identified, the sixteen expectations were provided on a series of "expectations cards." Participants were asked to include additional expectations if they were not covered in the list of sixteen. The participants were then asked to group these expectations cards into four categories of importance: most important, moderately important, low importance, and not important. Once they grouped all expectations into these four categories, participants were asked to again rank the expectations they had assigned to these four categories. Through this two-step sorting process expectations were ranked from highest (1) to lowest (16) in terms of their relative importance to the respondent. Following this assignment of relative importance, each participant was asked to indicate his/her perception about how well each expectation is being met within the target FMU, using a six-point scale ( 1 = fully met; 2 = mostly met; $3=$ some met; $4=$ only a little bit met; $5=$ not met at all; $6=$ don't know). Finally, participants were asked to consider a list of eight "forces" that might work to improve how well their expectations for forest management would be met in the future $^{6}$. The list of forces included: First Nation negotiations with the Ontario government, negotiation with industry, forest certification, improved business/profitability outlook for the forest industry, Aboriginal activism, court cases and legal decisions, increasing Aboriginal capacity, and Aboriginal claims filed with the federal government. Participants were asked to add additional forces they felt were missing and then to rank the forces list from the highest importance to the least importance.

\section{Statistical analysis}

The quantitative data collected through the community survey are ordinal, or rank data, and hence three non-parametric tests were used for statistical analysis of the data. The

\footnotetext{
${ }^{6}$ Parsons and Prest (2003) identified forest certification, landmark court cases, comprehensive and specific claims, and meaningful consultation with governments as the factors/process that influence Aboriginal satisfaction with forest management. Our Aboriginal partners and experts suggested that negotiation with industry, improved business/profitability outlook for the forest industry, Aboriginal activism as well as increased Aboriginal capacity can also influence satisfaction with forest management in Ontario. Hence, we used these eight forces, which are some sort of processes and/or factors, in our survey.
}

Friedman test, which is more general, was used to test whether differences exist between the rankings of different Aboriginal expectations, between the different Aboriginal expectation groups, or between the perceptions of Aboriginal satisfaction for different expectations or expectation groups. Once the significant differences in rankings of expectations and expectation groups and in levels of satisfaction related to these expectations were identified using the Friedman test, the Sign test was used to determine the order of ranking of respective expectations, expectation groups, and levels of satisfaction of expectations or expectation groups. Finally, the Kruskal-Wallis test was used to determine the differences in rankings across different groups, such as different First Nations and different user groups (Traditional Users, Commercial Users, and Leadership). All the statistical tests were performed at the $10 \%$ level of significance.

\section{Participants in the Community Research and their Knowledge about Forest Certification}

In total, thirty-five individuals participated in the 3CM exercises. Generally, these exercises were conducted with individual participants, but one session was conducted with a group of three elders from Mattagami First Nation, at their request. Hence, a total of 35 sessions were conducted. Individuals from three groups-Traditional forest users, Commercial forest users, and political/First Nation government Leadershipparticipated in these exercises. Group-wise distribution of the participants from the five First Nation communities is shown in Table 3. Out of 35 participants, 12 are from the two communities that have FSC-certified forests (Dokis and Mattagami), and the remaining 23 are from three other communities that did not have adjacent certified forests at the time of study. In total, there are 14 participants from the Leadership forest user group, 12 from the Traditional forest user group, and 9 from the Commercial forest user group.

Assessment of participants' awareness of forest certification in general, and of the forest certification status of forests in the respective Treaty area in particular, provided some very interesting results. First, in general, awareness of forest certification was extremely low. One-third of participants felt they were aware of forest certification in general. Only 17\%-or one in six-was aware of the forest certification status of forests in their Treaty area. Secondly, Commercial users of forests were generally more aware of forest certification than the other two groups, while the Traditional users of forest were almost entirely unaware of forest certification.

Even in the case of the two communities which have FSCcertified forests nearby (Dokis and Mattagami), people from the Traditional user group do not know either about forest 
certification in general, nor about the forest certification status of forests in their respective Treaty area. Finally, participants who knew about certified forests in their respective Treaty area also knew about forest certification in general.

\section{Aboriginal Expectations of Forest Management}

Only three respondents included any additional expectations to the supplied list of sixteen expectations. Therefore, we decided to conduct our further analysis with only the sixteen expectations that were identified during the open $3 \mathrm{CM}$ process. The first level of analysis focuses on identifying which of the expectations are most important to Aboriginal people in Ontario. This assessment was carried out on both the set of sixteen individual expectations, as well as on the four groups of aggregated expectations, as presented in Table 2. First, we test whether Aboriginal people assign statistically significant different ranks or not to the sixteen expectations. In other words we test the null hypothesis that "the rankings of the sixteen expectations are not significantly different among the members within each community." We test this hypothesis using the Friedman test for each of the five First Nations individually as well as for all participants together. Using this statistic, the null hypothesis is rejected for all five First Nations as well as for the combined population of thirtyfive Aboriginal people. We can conclude that Aboriginal people do not rank the sixteen expectations to be of equal importance.

The next step in analysis is to determine whether there are any patterns in how participants rank the various expectations. As a first step in seeking patterns in the expectations ranking, a simple graphical analysis of ranking of the sixteen expectations is presented in Fig. 1. The highest and lowest ranks (the extremes) assigned by any individual are represented by the lines-with the highest level representing a rank of " 1 ," or "most important" and the lowest level being " 16 ," or "least important." The area within the box represents the most common rankings - those provided by the middle half of all the respondents. ${ }^{\text {? }}$

It can be seen from Fig. 1 that six expectations-E.1, E.2, E.3, E.4, E.10 and E.11-stand out as being widely seen as of greatest importance. An interesting aspect here is that of these six expectations, four belong to the Aboriginal and Treaty Rights group and two to the Environmental Values and SFM group. Of the lowest importance are clearly E.14, E.12, and E.6. The remaining seven expectations fall into an intermediate level of importance.

Next we present, in Fig. 2, an analysis of the relative importance of the four groups of Aboriginal expectations, similar to the analysis of importance of the sixteen expectations presented above. As evident in Fig. 2, expectations related to

\footnotetext{
${ }^{7}$ The "box" is delimited by the first and third quartiles of respondents. Responses of thirty-three sessions were used in this ranking assessment. Thus, if all thirty-three individual rankings for a particular expectation are lined up, with rankings of " 1 " at the top and " 16 " at the bottom, then the ninth ranking down becomes the top of the box and the twenty-sixth ranking down indicates the bottom of the box. The horizontal line through the box indicates the median-or seventeenth-ranking. The vertical lines extend to the highest and lowest rankings assigned by any individual to that expectation.
}

Aboriginal and Treaty Rights (Group I) achieve the highest ranking, with those related to Environmental Values and SFM (Group III) gaining the second level of perceived importance. Expectations related to Participatory Decision-Making (Group II), and to Economic Opportunities and Development (Group IV) are typically ranked below these.

We tested these graphical results with the help of the Friedman test and the Sign test. Results for the sixteen expectations as well as results for the four groups were confirmed by these tests. For the ranking of the four groups, the Friedman test rejected the null hypothesis-that "the ranking of the four groups of Aboriginal expectations are not significantly different"-for the total population. The Sign test confirms that the Aboriginal and Treaty Rights group (Group I) is the most important and the Environmental Values and SFM group (Group III) is the second-highest ranked group. However, there is no statistical difference in the ranking of the Participatory Decision-Making and the Economic Opportunities and Development groups.

\section{Variation of Aboriginal expectations across different groups}

Next, we examined the variations in Aboriginal expectations across different groups-certified and non-certified forests, with and without certification knowledge, primary user groups, and five First Nations.

First, we tested the variation across communities with and without certified forests. We used the Kruskal-Wallis test to test the null hypothesis that "ranking of a given expectation (expectation group) is the same between the communities with and without certified forests." In the case of the four expectation groups, the null hypothesis is accepted for all four groups of expectations. This means that there is no statistical difference between the ranking of any of the four expectation groups across members from certified and non-certified forests. In the case of the sixteen individual expectations, there is a significant difference in the ranking of expectation E.5, meaningful involvement of First Nations, between people located near certified forests and those near non-certified forests, with those near non-certified forests ranking this expectation higher than the certified forest participants. There is no difference in the ranking of all other expectations by these two groups of participants.

Second, we tested whether respondents with forest certification knowledge in general rank four Aboriginal expectation groups differently than the respondents without this knowledge. An interesting aspect of these results is that Aboriginal and Treaty Rights, Environmental Values and SFM and Participatory Decision-Making are ranked to be more important by respondents with certification knowledge as compared to the respondents without certification knowledge, while in the case of Economic Opportunities and Development, the order of importance is opposite. However, the differences in these rankings are statistically significant only for Aboriginal and Treaty Rights and Economic Opportunities and Development.

Third, we tested whether the ranking of a given expectation group is the same across three categories of Aboriginal user groups, Traditional users, Commercial users, and Leadership. The test resulted in no statistical difference between the ranking of the three expectation groups-Aboriginal and Treaty Rights, Environmental Values, and Economic Opportunities and Development-by the different user groups. The 


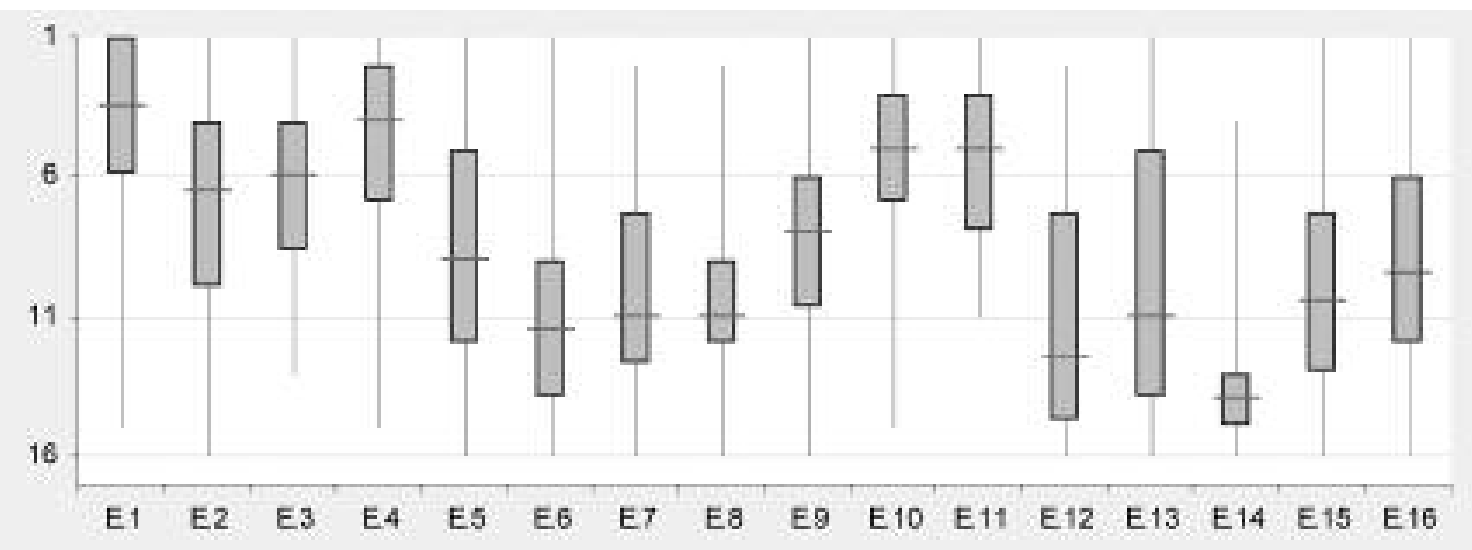

Fig. 1. Importance distribution of Aboriginal expectations from forest management.

Note: The highest and lowest ranks (the extremes) assigned by any individual are represented by the lines-with the highest level representing a rank of " 1 ," or "most important" and the lowest level being "16," or "least important." The area within the box represents the most common rankings - those provided by the middle half of all the respondents.

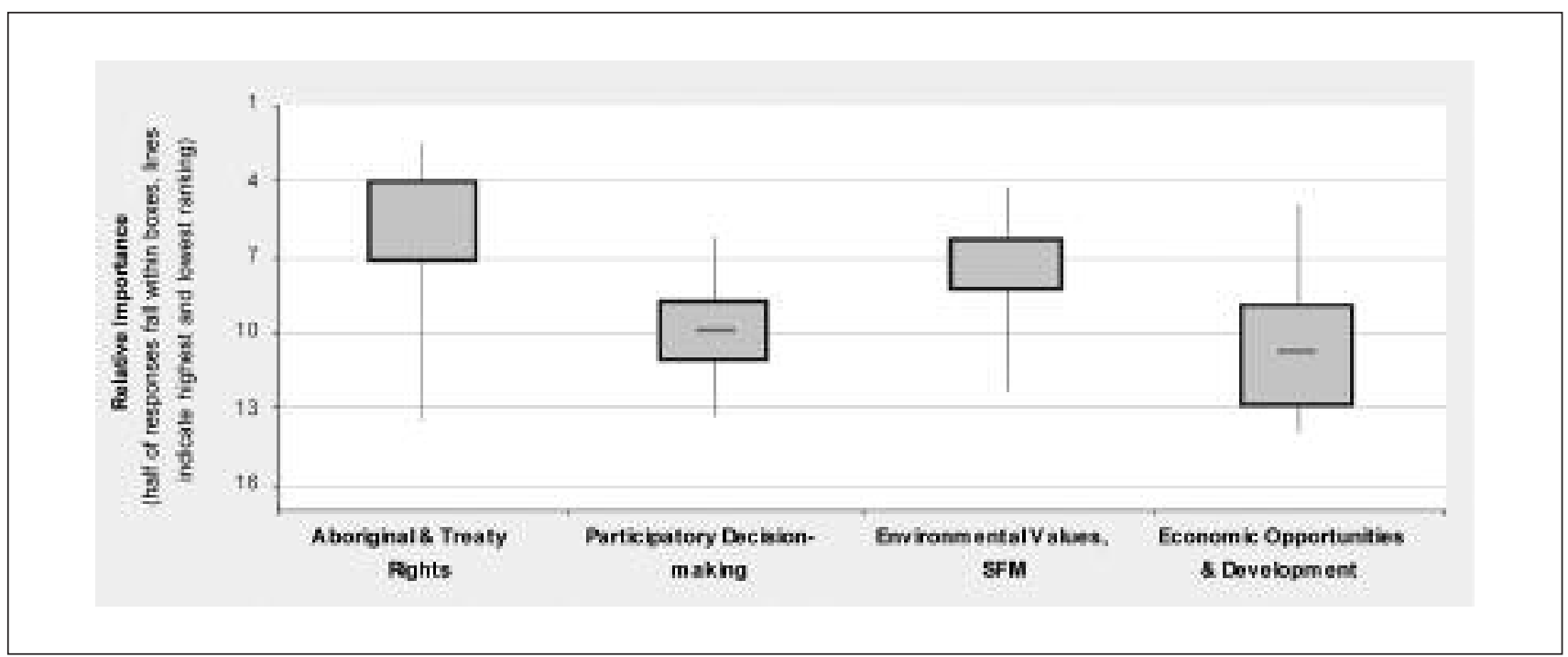

Fig. 2. Importance distribution of expectation groups.

Participatory Decision-Making group of expectations, however, was ranked significantly differently by the three groups, with Traditional users ranking these expectations to be more important than Leadership, and Leadership ranking it more important than the Commercial group.

In terms of individual expectations, Traditional users rank E.3, access to areas of importance, of higher importance than Commercial and Leadership respondents. In contrast, E.1, Aboriginal and Treaty rights, was ranked most highly by Commercial and Leadership. Traditional users also appeared to be more concerned with E.5, meaningful involvement, and E.6, regular reports from MNR and industry than either Commercial or Leadership respondents. Not surprisingly, perhaps, ranking of E.9, manage for other products, was more important to Traditional users than to the other respondent groups.
Also not surprising is the higher ranking of E.12, partnerships between industry, government and First Nations, and E.13, involvement by Aboriginal loggers, by Commercial users than by Traditional users.

Finally, we tested whether the ranking for a given expectation or group of expectations is the same across the five First Nations. In the case of the four expectation groups, the null hypothesis is accepted-there are no significant differences in the ranking of the four expectation groups across five First Nations. However, in the case of individual expectations, there were significant differences for E.3, E.5, E.6, E.9, and E.13. Access to areas of importance, E.3, is ranked higher by respondents from Mattagami, Pic River and Lac Seul, than by Dokis and Whitefish Lake respondents. Similarly, these three communities also rank E.6, regular reports by $M N R$ and 


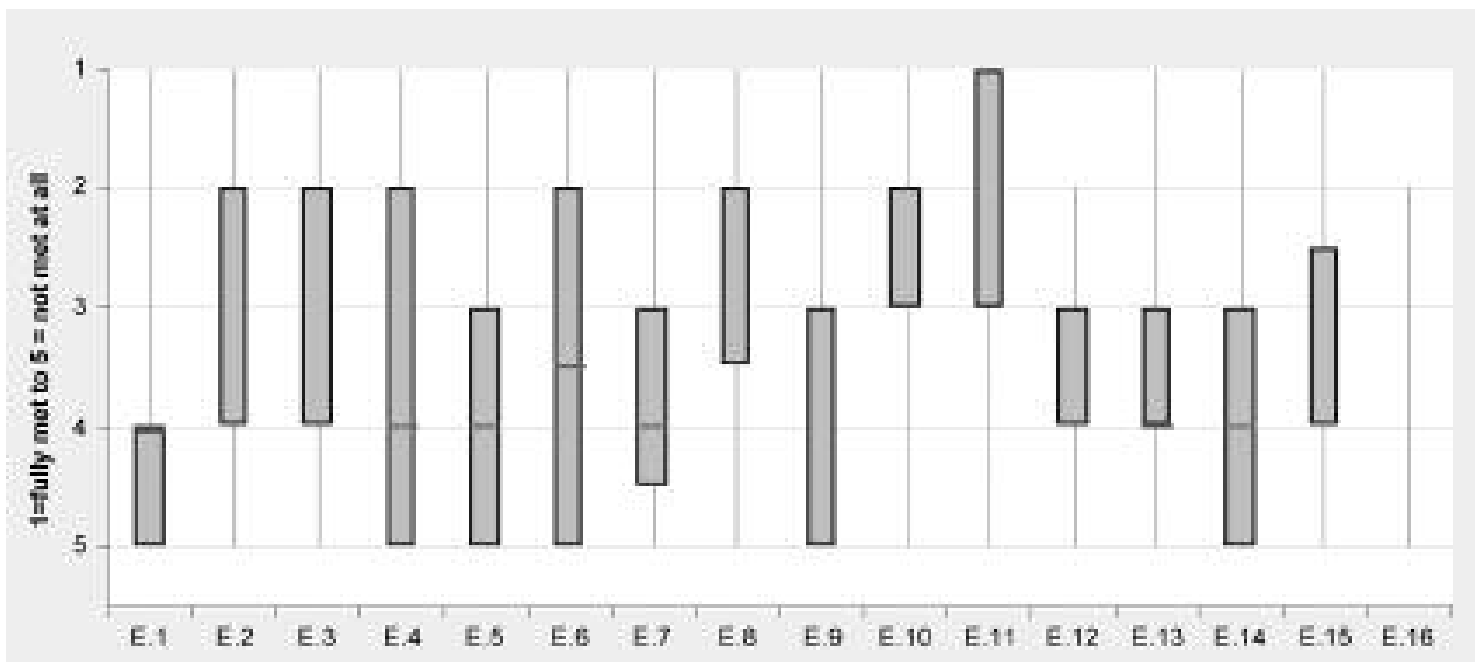

Fig. 3. Aboriginal perception of forest management with respect to Aboriginal expectations.

Note: The highest and lowest perception of how well an expectation has been met assigned by any individual is represented by the lines. A score of 1 = fully met, 2 = mostly met, $3=$ some met, 4 = only a little met, $5=$ not met at all. The area within the box represents the most common scores - those provided by the middle half of all the respondents. The median response is the middle response when all responses are lined up in order from highest to lowest level of satisfaction. The median score is represented by the solid line through the bar. Responses of "don't know" were not included in these analyses.

industry, higher than the latter two. Mattagami and Pic River respondents rank E.9, manage for other products, more highly than the other communities. E.5, meaningful involvement, is ranked much lower, and E.13, involvement by Aboriginal loggers, much higher, by Dokis respondents than by those from other communities.

\section{Aboriginal Perceptions of Forest Management with respect to Aboriginal Expectations}

A total of 32 respondents provided ratings for their perceptions of how most of the expectations were being met. Amongst these responses, 33 "don't know" responses, or 6\% of a total of 512 possible responses, were recorded. Hence, the analysis presented below is based on 479 responses. Fig. 3 presents the distribution of responses from all participants who were able to express their perceived level of satisfaction. A broad review of these responses suggests that respondents generally did not feel that forest management practices are meeting their expectations very highly. In one instance, E.16 (revenue sharing), at least half of all respondents indicated that this expectation is not being met at all. In seven expectations (E.1, E.4, E.5, E.6, E.7, E.13, E.14) the median rating was that the expectation was being met only a little bit. Only one expectation, E.11, protect water, wetlands, and watersheds, was considered to be mostly met by at least half of respondents. The results in Fig. 3 also indicate that Aboriginal perceptions of different expectations are different. This observation was tested by the Friedman test using the null hypothesis that "there are no significant differences in the rankings of the perceptions of forest management by Aboriginal people."

The null hypothesis is rejected, meaning that there are significance differences in the ranking of perceptions of how well different expectations of forest management are being met. To illustrate some of this difference in perception, the median responses for the perceptions of each of sixteen expectations are given in Table 5.

As the results indicate, none of the expectations were perceived to be fully met by at least half of all respondents. In addition, only one expectation, E.11, protect water, wetlands, and watersheds, is perceived to be mostly met or better by half of the respondents, while one other expectation, sharing of revenue from treaty forest land, is perceived to be not met at all by at least half of all respondents. Median responses for perceptions related to eight other expectations are some met and to the remaining six expectations are only a little bit met.

Finally, we tested the perceptions of the level of satisfaction related to the four major groups of expectations. Graphical analysis is given in Fig. 4 and suggests that Aboriginal participants perceive that their expectations related to Environmental Values and SFM (Group III) are being better met than their expectations in the other major areas of Aboriginal and Treaty Rights (Group I), Participatory Decision-Making (Group II), and Economic Opportunities and Development (Group IV). These results were tested statistically using the Friedman test. In this case, we tested the following null hypothesis- "there are no significant differences in the rankings of the perceptions of the level of satisfaction of the four main groups of expectations by Aboriginal People." The null hypothesis is rejected, which means that there are significant differences in the ranking of the perceptions of the level of satisfaction of the four main groups of expectations. The results of the Sign test confirm that Aboriginal people perceive that their expectations related to Environmental Values are met to a higher degree than those related to the three other expectation groups. 
Table 4. Importance and the level of satisfaction for the four groups of expectations

How Well Expectation Is Met Importance

Higher Satisfaction

Group III: Environmental Values and SFM
Top Importance

Group I: Aboriginal and Treaty Rights

Second Importance

Group III: Environmental Values and SFM

\section{Lower Satisfaction}

Group I: Aboriginal and Treaty Rights

Group II: Participatory Decision-Making

Group IV: Economic Opportunities and Development
Third Importance

Group II: Participatory Decision-Making

Group IV: Economic Opportunities and Development

Table 5. Importance and the level of satisfaction for the sixteen expectations

Expectation

Level of Satisfaction

(Median Response)

\section{Top Importance}

E.1 Recognize and implement Aboriginal and Treaty rights ensure that Aboriginal People can exercise their rights without interference.

E.2 Identify and map areas of importance to Aboriginal People (such as hunting and trapping, sacred areas, medicinal plant areas, and others).

E.3 Ensure that Aboriginal People have access to areas of importance to them such as hunting and trapping, Partly Met sacred areas, medicinal plant areas, areas for raw materials for crafts, firewood, and other areas.

E.4 Protect areas of importance to Aboriginal People such as hunting and trapping, sacred areas, medicinal

Little or Not at all

E.10 Protection of wildlife and their habitat protect and sustain the whole forest ecosystem.

Partly Met

E.11 Protect water, wetlands, and watersheds.

Mostly Met

Intermediate Importance

E.5 Meaningful involvement of First Nations in decisions about how Treaty forest lands are managed and used.

Little or Not at all

E.7 Incorporate Aboriginal knowledge into forest management planning and operations.

(Traditional Ecological Knowledge, Indigenous knowledge systems)

E.8 Tree-planting and other regeneration and management practices on Crown forest lands to ensure that opportunities for future timber harvests for Aboriginal People are sustained.

Little or Not at all

E.9 Manage forests to ensure that forest products (such as berries, bark, nuts, medicines, and other items) ... are available for Aboriginal People to use now and in the future.

E.13 Increased involvement by Aboriginal loggers in harvesting timber from Treaty forest lands. Partly Met

E.15 Education, training and capacity-building programs for Aboriginal People related to forest management, employment and business opportunities.

E.16 Sharing of the revenues from Treaty forest lands to support Aboriginal self-government.

Little or Not at all

Partly Met 


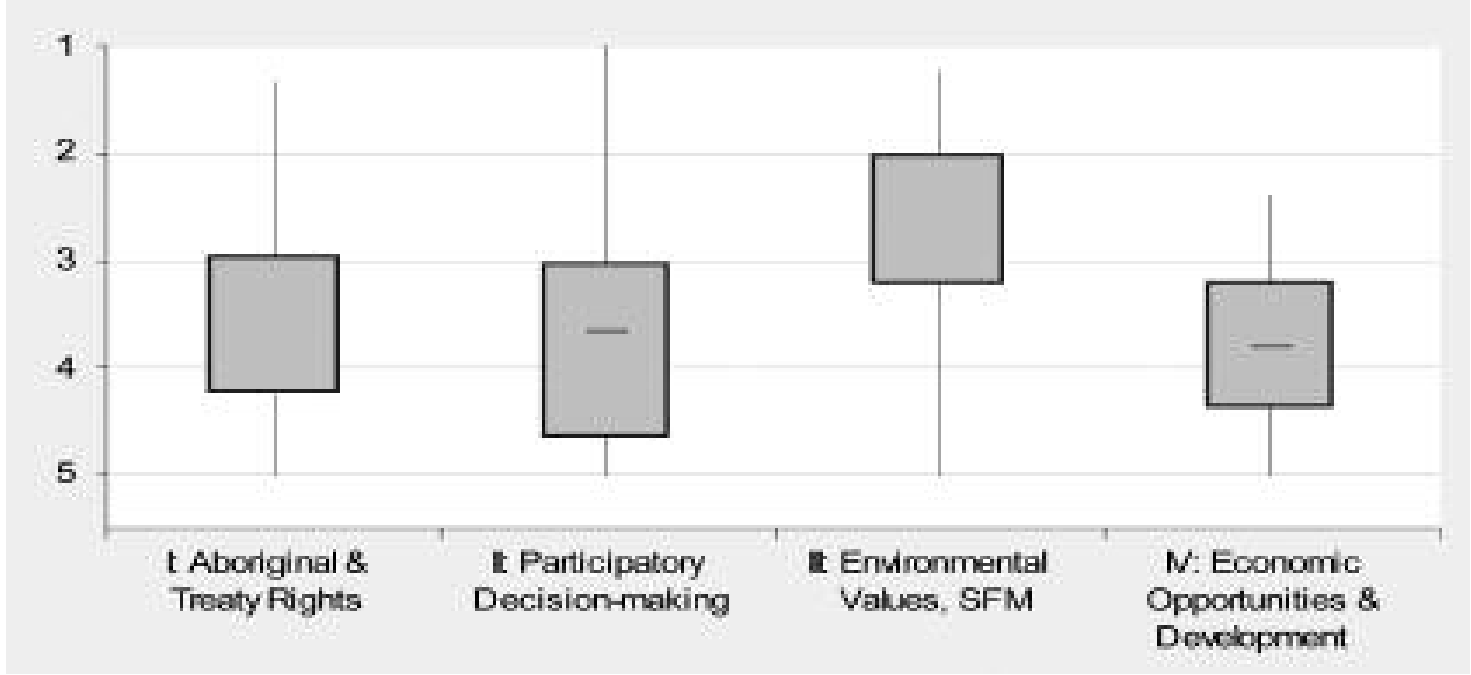

Fig. 4. Aboriginal perceptions of forest management with respect to Aboriginal expectation groups Note: 1 = fully met, 2 = mostly met, 3 = some met, 4 = only a little met, 5 = not met at all. Responses of "don't know" were recorded but not included in the analysis.

\section{Variation of Aboriginal perceptions across different groups} As with the analysis of Aboriginal expectations, we examined variation in Aboriginal perceptions across different groupscertified and non-certified forests, with and without certification knowledge, primary user groups, and the five First Nations.

First, we tested the variation across communities with and without certified forests using the Kruskal-Wallis test. The null hypothesis is that "ranking of a given perception is the same between the communities with and without certified forests." The test indicates that in general, the mean level of satisfaction of people relating to certified forests is higher than that of people relating to non-certified forests for all expectations except E.1 (The recognition and implementation of Aboriginal and treaty rights). However, in the case of eleven expectations, this difference is not significant. In the case of the remaining five expectations-E.3, E.5, E.10, E.11, and E.16 - the difference is significant. People relating to certified forests perceive that these latter five expectations are being met to a higher degree than people relating to non-certified forests. The pattern of higher levels of satisfaction with forest management in certified forests is also apparent when expectations are considered within the four major expectation groupings. As per the results of the Kruskal-Wallis test, the mean level of satisfaction for all four expectation groups of people relating to certified forests is higher than that of people relating to the non-certified forest group. However, a significant difference between the certified and non-certified forest groups is only identified in the case of the Participatory Decision-Making group of expectations.

Second, we tested whether respondents with general knowledge of forest certification have different levels of perceived satisfaction related to the four expectation groups, as compared to the level of satisfaction of respondents without knowledge of forest certification. In this case, the null hypothesis is accepted for Aboriginal and Treaty Rights, Environmental Values and SFM, and Economic Opportunities and Development, while it is rejected for Participatory Decision-Making indicating that Aboriginal people with certification knowledge are more satisfied with Participatory Decision-Making than those without certification knowledge.

Third, in the case of the three user groups, the null hypothesis-that "the level of satisfaction is the same across the three user groups" -is accepted in the case of Aboriginal and Treaty Rights and Economic Opportunities and Development, but rejected in the case of the other two expectation groups. In the case of Environmental Values and SFM, the degree of satisfaction is the highest amongst the Commercial group and the lowest amongst the Traditional group. In the case of Participatory Decision-Making expectations, the degree of satisfaction is the highest for Leadership and lowest for the Commercial group.

In terms of individual expectations, Traditional users are less satisfied with how well their expectations related to E.2, Identify and map areas of importance, and E.3, Access to areas of importance, are being met. Commercial users are less satisfied than either the Leadership or the Traditional user groups with how well their expectations are being met around E.6, Regular reports by MNR and Industry, and around E.15, Capacity building. The greatest divergence of Traditional users from the other user groups in the area of Environmental Values arises with respect to E.10, Protection of wildlife and habitat, and E.11, Protect water, wetlands, watersheds. The expectations of half of all Commercial and Leadership respondents related to E.10 were perceived to be mostly met or fully met. Amongst Traditional users, the median response 


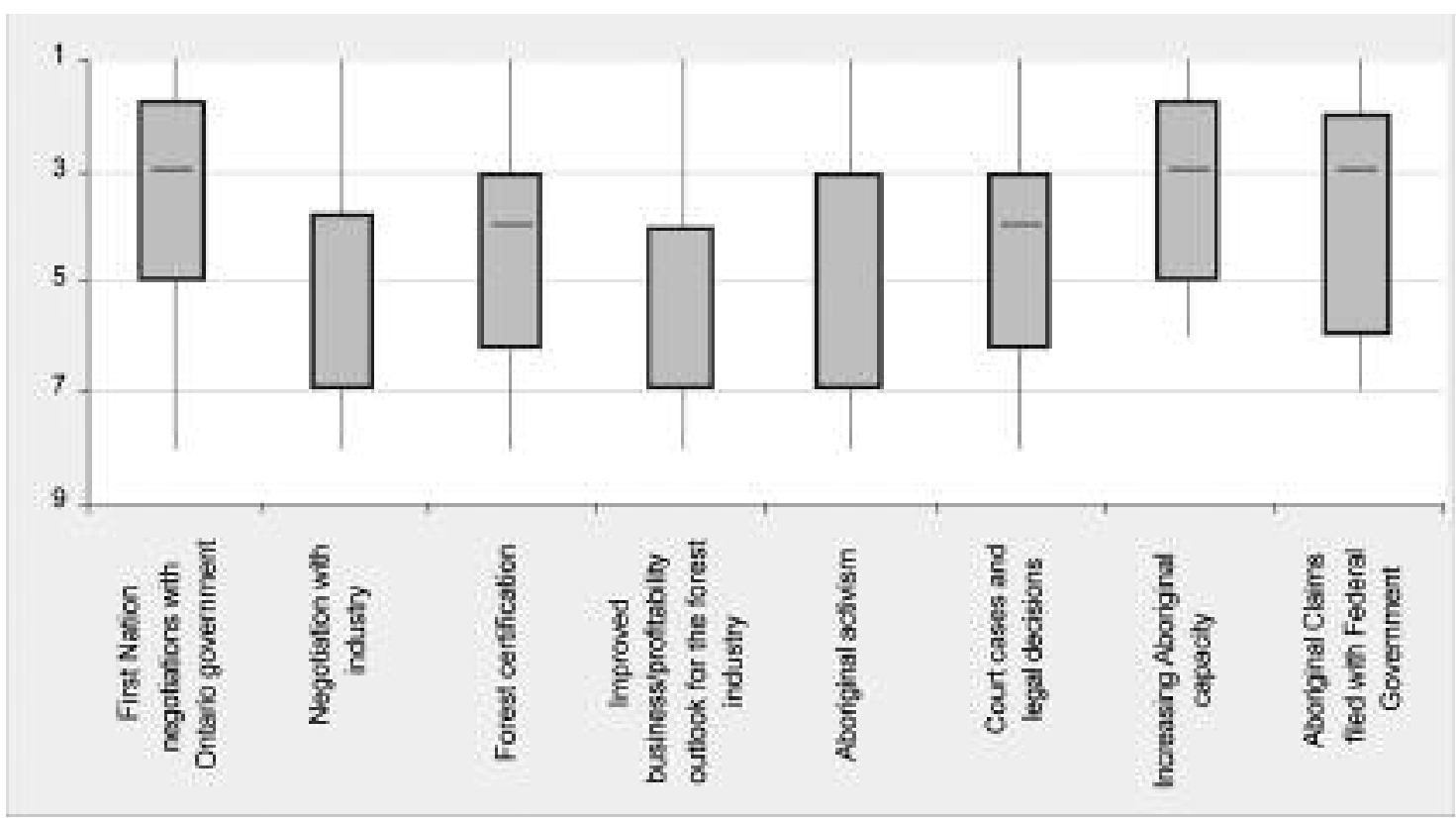

Fig. 5. Perceived effectiveness of forces to achieve Aboriginal forest management expectations.

was only some met. The perception of Traditional users related to E.11 was that amongst half of this user group this expectation was perceived to be only a little met or worse. The other half felt that their expectations were either some met or mostly met. Half of the Commercial respondents felt that their expectation related to E.11, Protect water, wetlands, and watersheds was fully met. Half of the Leadership respondents felt this expectation was mostly met or better-with one-quarter indicating their expectation was fully met.

Finally, for the analysis of the five individual First Nations, the null hypothesis that "the level of satisfaction is the same across First Nations" is accepted in the case of Aboriginal and Treaty Rights and Participatory Decision-Making, but rejected in the case of the other two expectations, Environmental Values and SFM and Economic Opportunities and Development. The interesting aspect of these results is that Lac Seul participants seem to be less satisfied, while Mattagami respondents are the most satisfied for each of the expectation groups, while the level of satisfaction of respondents from the remaining three communities falls in the middle. We can conclude that the First Nation community in which participants live is a significant factor in explaining some of the variation in satisfaction levels related to Environmental Values and SFM and Economic Opportunities and Development expectations. These expectation groups were not significantly different based on certification status of forests, therefore some other characteristics related to the community-forest pairs must account for this difference.

\section{Aboriginal Perceptions of Forces of Change}

Participants ranked the eight forces expected to improve how well forest management meets their expectation from " 1 " for the highest importance, to " 8 " for the least important force. ${ }^{8}$ Fig. 5 illustrates the distribution of rankings from the thirtyfive participants who completed this exercise. The figure indicates that Aboriginal people perceive First Nation negotiations with the Ontario government, Increasing Aboriginal capacity, and Aboriginal claims filed with the federal government as the most important forces of change, and Improved business/profitability outlook for the forest industry and Aboriginal activism as the least important forces of change. The remaining three forces-Negotiation with industry, Forest certification and Court cases and legal decisions - are perceived as the forces of medium importance.

We tested the statistical significance of these differences of rankings of importance of the eight forces of change. The results of the Friedman test indicated that the null hypothesis - that "the ranking of eight forces of change is the same"is rejected. Hence, we conducted the Sign test to determine the order of ranking of the eight forces of change. There are four main inferences from the Sign test results. First, there are no significance differences in the ranking of three forces for change: First Nation negotiations with the Ontario government (F.1), Increasing Aboriginal capacity (F.7), and Aboriginal claims filed with the federal government (F.8). Second, three forces of change, Negotiation with industry (F.2), Improved business/profitability outlook for the forest industry (F.4), and Aboriginal activism (F.5), are ranked less important than F.1, F.7, and F.8. Third, there are no significance differences in the ranking of Forest Certification (F.3) compared

${ }^{8}$ Three participants assigned the same rank for more than one force of change and, therefore, their ranks do not range from 1 to 8 . 
to the ranking of First Nation negotiations with the Ontario government (F.1), Negotiation with industry (F.2), Improved business/profitability outlook for the forest industry (F.4), and Court cases and legal decisions (F.6), and Aboriginal claims filed with the federal government (F.8). Forth, Forest certification (F.3) is ranked significantly higher than Aboriginal activism (F.5) and significantly lower than Increasing Aboriginal capacity (F.7).

\section{Variation of aboriginal perceptions of forces of change across different groups}

To better understand the perception that Aboriginal people have of the forces that may improve how their expectations are met, the "forces dataset" was analyzed based on the certification status of the target forest, the respondent's primary relationship to the forest, and the First Nation community. In the case of certification status, our null hypothesis is "a force for change is ranked the same by the respondents relating to either certified or non-certified forests." The null hypothesis is accepted for all forces of change except Improved business/ profitability outlook for the forest industry, which is ranked more important by respondents relating to certified forests as compared to respondents relating to non-certified forests.

For analysis of the three user groups, our null hypothesis is "a force for change is ranked the same by the respondents from the Traditional user group, Commercial user group, and Leadership." As per the results of the Kruskal-Wallis test, the null hypothesis is accepted for all forces of change except Negotiations with Industry, which is ranked as more important by respondents from the Leadership group as compared to respondents from either the Traditional or Commercial user groups.

For analysis of responses across the five First Nations, the null hypothesis is "a force for change is ranked same by the respondents from five First Nations." Again using the Kruskal-Wallis test, the null hypothesis is accepted for all forces of change. Therefore we conclude that there is no evidence of any significant difference in the ranking of a force for change across the five First Nation communities.

\section{Summary and Conclusions}

This study, as we stated in the Introduction, is the first study that has attempted to quantify Aboriginal peoples' expectations of Crown forest management and their perceptions of the extent to which forest management practices in Ontario meet these expectations. Hence, we are unable to conduct comparative analyses of our results with the previous studies. In general, the four major groups of Aboriginal expectations as we found in our study-Aboriginal and Treaty Rights, Environmental Values, Participatory Decision-Making, and Economics Opportunities - are similar to many discussions, such as Parsons and Prest 2003, Lee and Kant 2006, Merkel 2007 and Wyatt 2008, about Aboriginal values. However, the previous studies neither ranked the importance of these major groups of expectations nor quantified the level of satisfaction of Aboriginal people.

According to this study, Aboriginal people place the highest importance on the group of expectations related to Aboriginal and Treaty Rights-recognition and implementation of Aboriginal and treaty rights, identification and protection of areas of importance to Aboriginal Peoples, and ensuring that
Aboriginal Peoples have access to these areas. The secondhighest level of importance is placed on the group of expectations related to Environmental Values and SFM. Expectations related to Participatory Decision-Making and Economic Opportunities and Development are ranked equal to each other, and of lower importance than the other two groups. The study has also demonstrated a generally good consistency in the expectations that Aboriginal people feel should be met by forest management taking place within their traditional territories.

Consistency is also found in how well Aboriginal people perceive current forest management practices are meeting their expectations. Aboriginal people generally perceive that forest management is meeting their expectations related to Environmental Values and SFM better than it is meeting their expectations related to Aboriginal and Treaty Rights, Participatory Decision-Making, and Economic Opportunities and Development. These results are shown in Table 4 .

In terms of individual expectations, of the six expectations ranking of highest importance, two (E1 and E4) are met only a little or not at all, three (E2, E3, and E10) are partly met, and one (E11) is mostly met. Of the seven expectations of intermediate importance, four (E5, E7, E13, and E16) are met a little or not at all, and three (E8, E9, and E15) are partly met. Of the three expectations of low importance, one (E14) is met a little or not at all, and two (E6 and E12) are partly met. Details of these results are presented in Table 5 .

Our research also explored variation in the general pattern of Aboriginal expectation and perception arising from attributes related to forest certification and an individual's relationship to the forest. We conclude that the certification of forests has hardly had any impact on the importance assigned by Aboriginal people to different expectation groups or different individual expectations, except that E.5, Meaningful involvement of First Nations in decisions about how Treaty forest lands are managed and used, was ranked significantly higher by the participants from First Nation communities near non-certified forests than those from communities where the nearby forest is certified. However, Aboriginal people from First Nation communities near certified forests were either equally satisfied or more satisfied with how well forest management meets their expectations. Participants considering forest management under certified forest conditions were more satisfied in relation to E.3, ensuring access; E.5, meaningful involvement; E.10, protection of wildlife and habitat; E.11 protect water; and E.16, sharing of revenues. Similarly, the level of satisfaction with expectations related to the Participatory Decision-Making group is higher amongst Aboriginal participants relating to certified forest units than amongst those relating to non-certified forests. This suggests that forest certification is having some effect on meeting Aboriginal expectations.

Having a general knowledge of forest certification has some diverse effects on expectations and perceptions. Aboriginal and Treaty Rights was ranked significantly more important, while Economic Opportunities and Development was ranked significantly less important by respondents with certification knowledge, as compared to respondents without certification knowledge. Also, Aboriginal people with certification knowledge are more satisfied with the Participatory Decision-Making expectation group than those without certification knowledge. 
In terms of user groups, Traditional forest users ranked the Participatory Decision-Making expectations to be more important than the Leadership group, and the Leadership group ranked it more important than the Commercial group. Leadership participants express a higher level of satisfaction with how Participatory Decision-Making expectations are being met than does the Commercial forest user group. The other three expectation groups were ranked in the same way by the three user groups. However, Commercial forest users are more satisfied than are Traditional forest users with Environmental Values and SFM while there is no difference in the perceptions of two other expectations groups-Aboriginal and Treaty Rights and Economic Opportunities and Development-between different forest user groups. While there was no significant difference in the importance of any of the four Aboriginal expectation groups across the different First Nations, the perceived satisfaction levels for Environmental Values and SFM and Economic Opportunities and Development do vary across the First Nations.

Aboriginal respondents perceived First Nation negotiations with the Ontario government, Increasing Aboriginal capacity, and Aboriginal claims filed with the federal government to be of high, and equal, importance. Three other forces of change-Negotiation with industry, Improved business/profitability outlook for the forest industry, and Aboriginal activism - are perceived to be of low importance. Forest certification is perceived to be as important as First Nation negotiations with the Ontario government, Negotiation with industry, Improved business/profitability outlook for the forest industry, Court cases and legal decisions, and Aboriginal claims filed with the federal government. In addition, Forest certification is perceived to be more important than Aboriginal activism and less important than Increasing Aboriginal capacity.

There is no significant difference in the perception of Aboriginal people from certified and non-certified forest areas with respect to the importance of different forces of change, except that Improved business/profitability outlook for the forest industry is ranked more important by respondents from First Nations having certified forests. Similarly, there is no significant difference in the perception of Aboriginal respondents with respect to the importance of different forces of change that can be attributed to the community of residence of the respondents. Respondents in the Leadership user group perceived Negotiation with industry to be a more important force for changing how their expectations with respect to forest management are going to be met than did Commercial or Traditional forest users.

Our finding that Aboriginal people across Ontario share, to a large degree, a common set of expectations related to forest management means that it should be possible to meet these expectations, to a large degree, by applying a consistent set of management practices. However, our exploration of variation in these expectations means that forest management practices will always need to be fine-tuned through well-targeted consultation processes in order to achieve the highest level of performance relative to Aboriginal expectations related to any particular forest unit. Our research suggests that an important dimension of this targeting will be to consider the different Aboriginal groups that use the forest. These groups should be identified and consulted with individually in order to ensure that the full range of concerns and priorities are brought to the table during forest management planning.

Finally, as we stated in the introduction, this paper covers only the first part of our research project. The second part of the project, which examines the adequacy of Ontario's Forest Management Planning Manual and the FSC and CSA Standards of Forest Certification with respect to sixteen Aboriginal expectations, will be available in the second paper-probably in this journal. We believe that the second paper will provide the full picture and utility of our work presented in this paper.

\section{Acknowledgements}

The authors would like to extend appreciation to all those who contributed to this study. In particular, the assistance of community liaison workers in the five participating First Nation communities, along with the communities themselves, is recognized. The field assistance provided by Sarah Allen is noted with appreciation. We would also like to acknowledge the financial support to this project from the Ontario Ministry of Natural Resources (through the Enhanced Forest Productivity Science Project of the Forestry Futures Trust); the Canadian Boreal Initiative; and Natural Resources Canada (NRCan) and Indian and Northern Affairs Canada (INAC), who jointly provided funding assistance through the First Nations Forestry Program. Finally, the contribution of the National Aboriginal Forestry Association in supporting the design, logistics, and administration of this project is recognized.

\section{References}

Brubacher, D. 1998. Aboriginal forestry joint ventures: Elements for an assessment framework. The Forestry Chronicle 74(3): 353-358. Canadian Council of Forest Ministers (CCFM). 1995. Defining sustainable forest management: A Canadian Approach to Criteria and Indicators. Ottawa. $22 \mathrm{p}$.

. 1998. National Forest Strategy (2003-2008), A Sustainable

Forest: The Canadian Commitment Ottawa. $47 \mathrm{p}$.

2003. Defining sustainable forest management in Canada:

Criteria and Indicators in 2003. Ottawa. 20 p.

Castro, A.P. and E. Nielson. 2001. Indigenous people and co-management: Implications for conflict management . Environmental Science Policy 4: 229-239.

Environmental Assessment Board (EAB). 1994. Class environmental assessment by the Ministry of Natural Resources for Timber Management on Crown lands in Ontario. Government of Ontario, Toronto, ON. 561 p.

Forest Certification Watch. 2005. [online]. Available at http://certificationwatch.org [Accessed March 31, 2005].

Graham, J. 1999. Exploring the relationship between Aboriginal peoples and the Canadian forest industry. The Forestry Chronicle 75(1): 67-72.

Hickey, C. and M. Nelson. 2005. Partnerships between First Nations and forestry sector: a national survey. Sustainable Forest Management Network, Edmonton, AB.

Kant, S. and S. Lee. 2004. A social choice approach to sustainable forest management: an analysis of multiple forest values in Northwestern Ontario. Forest Policy and Economics 6: 215-227.

Kearney, A.R., G. Bradley, R. Kaplan and S. Kaplan. 1998. Stakeholder perspectives on appropriate forest management in the Pacific Northwest. Forest Science 45(1): 62-73.

Kearney, A.R. and S. Kaplan. 1997. Towards a methodology for the measurement of knowledge structures of ordinary people: the Con- 
ceptual Content Cognitive Map (3CM). Environment and Behaviour 29(5): 579-617.

Lee, S. and S. Kant. 2006. Personal and group forest values and perceptions of groups' forest values in Northwestern Ontario. The Forestry Chronicle 82(4): 512-520.

Lertzman, D.A. 1999. Planning between cultural paradigms: Traditional knowledge and the transition to ecological sustainability. Ph. D. Thesis, University of British Columbia, Vancouver, BC.

Mabee, H. and G. Hoberg. 2006. Equal partners? Assessing comanagement of forest resources in Clayoquot Sound. Society and Natural Resources 18: 875-888.

McGregor, D. 2000. From exclusion to co-existence: Aboriginal participation in Ontario Forest Management Planning. Doctoral Thesis, University of Toronto, ON. 254 p.

McGregor, D. 2002. Indigenous knowledge in sustainable forest management: community-based approaches achieve greater success. The Forestry Chronicle 78(6): 833-836.

Merkel, G. 2007. We are all connected: Globalization and community sustainability in the boreal forest, an Aboriginal perspective. The Forestry Chronicle 83(3): 362-366.

National Aboriginal Forestry Association and the Institute of Governance, (NAFA-IOG). 2000. Aboriginal-forest sector partnerships: lessons for future collaboration. Ottawa, ON.

Notzke, C. 1995. A new perspective in Aboriginal natural resource management: Co-management. Geoforum 26(2): 187-209.
Ontario Ministry of Natural Resources (OMNR). 1995. Crown Forest Sustainability Act.

Parsons, R. and G. Prest. 2003. Aboriginal Forestry in Canada. The Forestry Chronicle 79(4): 779-784.

Rusnak, G. 1997. Co-management of natural resources in Canada: A review of concepts and case studies. IDRC, Ottawa, ON.

Sherry, E. and H. Myers. 2002. Traditional environmental knowledge in practice. Society and Natural Resources 15: 345-358.

Smith, P. 2007. Creating a new stage for sustainable forest management through co-management with Aboriginal people in Ontario. Ph. D. Thesis, University of Toronto, Toronto, ON. 358 p.

Stevenson, M. 2006. The possibility of difference: rethinking comanagement. Human Organization 65: 167-180.

Treseder, L. and N. Krogman. 2000. The effectiveness and potential of the Caribou-Lower Peace Cooperative Forest Management Board. SFMN, Edmonton, AB.

Trosper, R., H. Nelson., G. Hoberg., P. Smith and W. Nikolakis. 2008. Institutional determinants of profitable commercial forestry enterprises among First Nations in Canada. Canadian Journal of Forest Research 38: 226-238.

Wyatt, S. 2008. First Nations, forest lands, and "aboriginal forestry" in Canada: from exclusion to co-management and beyond. Canadian Journal of Forest Research 38: 171-180. 